\title{
GAMBARAN SIKAP DAN PERILAKU TERHADAP KARIES GIGI PADA SISWA SD INPRES PATTIRO KEC. MANUJU KAB. GOWA
}

\author{
Pariati, Wahyudin \\ Stikes Amanah Makassar
}

\begin{abstract}
ABSTRAK
Kesehatan gigi dan mulut merupakan bagian dari kesehatan tubuh yang tidak dapat dipisahkan satu dengan yang lainnya karena akan mempengaruhi kesehatan tubuh keseluruhan. Sebagian besar masyarakat tidak menyadari awal mula timbulnya penyakit gigi dan mulut bersumber dari kesehatan rongga mulut secara menyeluruh. Hal ini dipengaruhi oleh faktor perilaku masyarakat yang kurang peduli akan kebersihan gigi dan mulut yang dijadikan suatu kebiasaan dan budaya. Karies gigi adalah penyakit infeksi dan merupakan suatu proses demineralisasi yang progresif pada jaringan keras permukaan mahkota dan akar gigi yang dapat dicegah. Prevalensi karies masih cukup tinggi di seluruh dunia, sehingga karies merupakan suatu penyakit infeksi gigi yang menjadi prioritas masalah kesehatan gigi dan mulut. Berdasarkan data awal yang telah dilakukan pada SD Inpres Pattiro Kec. Manuju Kab. Gowa, sebanyak 39 siswa yang diperiksa dan semua siswa mengalami karies. Tujuan penelitian ini untuk mengetahui Gambaran Sikap dan Perilaku Terhadap Karies Gigi Pada Siswa SD Inpres Pattiro Kec. Manuju Kab. Gowa dengan melakukan metode penelitian deskriktif dengan pendekatan observasional dengan menggunaka kuesioner dan lembar observasi. Hasil menunjukkan bahwa semakin baik sikap dan perilaku siswa maka cenderung semakin rendah pula tingkat keparahan kariesnya.
\end{abstract}

Kata Kunci: Karies Gigi, Perilaku, Sikap

\section{PENDAHULUAN}

Kesehatan gigi dan mulut merupakan bagian dari kesehatan tubuh yang tidak dapat dipisahkan satu dengan yang lainnya karena akan mempengaruhi kesehatan tubuh keseluruhan. Sebagian besar masyarakat tidak menyadari awal mula timbulnya penyakit gigi dan mulut bersumber dari kesehatan rongga mulut secara menyeluruh. Hal ini dipengaruhi oleh faktor perilaku masyarakat yang kurang peduli akan kebersihan gigi dan mulut yang dijadikan suatu kebiasaan dan budaya.

Karies gigi adalah penyakit infeksi dan merupakan suatu proses demineralisasi yang progresif pada jaringan keras permukaan mahkota dan akar gigi yang dapat dicegah. Prevalensi karies masih cukup tinggi di seluruh dunia, sehingga karies merupakan suatu penyakit infeksi gigi yang menjadi prioritas masalah kesehatan gigi dan mulut.

$$
\text { Hasil Riset Kesehatan Dasar }
$$

(RISKESDAS) tahun 2013 menunjukkan status karies penduduk Indonesia usia diatas 12 tahun yang dinilai menggukanan index DMF-T sebesar 4,6. Artinya kerusakan gigi penduduk
Indonesia 460 buah gigi per 100 orang. Jumlah ini terbilang masih tinggi untuk kejadian karies penduduk Indonesia. Salah satu Provinsi yang index DMF-Tnya tinggi adalah Sulawesi Selatan yaitu sebesar 5,5 .

Sikap merupakan reaksi atau respon yang masih tertutup dari seseorang terhadap suatu stimulus atau objek. Manifestasi sikap tidak dapat langsung terlihat tetapi hanya dapat ditafsirkan terlebih dahulu dari perilaku yang tertutup. Sikap secara nyata menunjukkan konotasi adanya kesesuaian reaksi terhadap stimulus tertentu yang dalam kehidupan seharihari merupakan reaksi yang bersifat emosional terhadap stimulus sosial. Pengukuran sikap dapat dilakukan secara langsung dengan menanyakan bagaimana pendapat atau peryataan responden terhadap suatu objek. (Notoadmodjo S, 2007 kutipan Nurjannah 2016).

Dikutip dari Prasetya (2012) Benyamin Bloom membagi perilaku manusia menjadi 3 domain sesuai dengan tujuan pendidikan. Bloom menyebutkan 3 ranah yakni kognitif, afektif, dan psikomotor. Dalam 
perkembangannya, teori Bloom ini dimodifikasi untuk pengukuran hasil pendidikan kesehatan yakni pengetahuan, sikap, dan praktik/tindakan. (Prasetya Tri I, 2012 kutipan Arifah, Ainun N. 2016).

Perilaku kesehatan gigi meliputi pengetahuan, sikap dan tindakan yang berkaitan dengan konsep sehat dan sakit gigi serta upaya pencegahannya. Konsep kesehatan gigi adalah gigi dan semua jaringan yang ada di dalam mulut, termasuk gusi dan jaringan sekitarnya. (Budiharto, 2013 kutipan Arifah, Ainun N. 2016).

Pengukuran perilaku dapat dilakukan secara tidak langsung yakni dengan wawancara terhadap kegiatan-kegiatan yang telah dilakukan beberapa jam, hari atau bulan lalu (recall). Pengukuran juga dapat dilakukan secara langsung, yakni dengan mengobservasi tindakan atau kegiatan responden. (Notoadmodjo S, 2007 kutipan Nurjannah, 2016).

Perubahan perilaku dan indikatornya. Menurut Notoadmodjo S, (2007) kutipan Nurjannah, (2016) perubahan atau adopsi perilaku baru adalah suatu proses yang kompleks dan memerlukan waktu yang relatif lama. Secara teori, perubahan perilaku atau seseorang menerima atau mengadopsi perilaku baru dalam kehidupannya melalui 3 tahap.

\section{METODE PENELITIAN}

Penelitian ini merupakan penelitian deskriptif dengan pendekatan observasional dengan menggunaka kuesioner dan lembar observasi, dengan tujuan untuk mengetahui gambaran sikap dan perilaku terhadap karies gigi pada siswa SD Inpres Pattiro Kec. Manuju Kab. Gowa. Penelitian ini akan dilaksanakan di SD Inpres Pattiro Kec. Manuju Kab. Gowa Provinsi Sulawesi Selatan. Penelitian dilaksanakan pada bulan Juni - Juli 2018.

Populasi penelitian ini adalah semua siswa SD Inpres Pattiro kec. Manuju kab. Gowa yang berjumlah 96 siswa dari kelas I-VI. Sampel dalam penelitian ini Dilakukan dengan teknik purposive sampling yaitu diambil sesuai kebutuhan berdasarkan kriteria yang ditetapkan oleh peneliti yaitu berjumlah 34 siswa, yakni kelas I (11 siswa), kelas II (9 siswa,) dan kelas III (14 siswa).

Penilaian sikap diukur dengan menggunakan skala Likert, skala likert dibuat oleh Rensis Likert (1932) yang berasal dari Amerika Serikat dalam Lentera Pena (2012), dengan memberikan 10 pernyataan, kemudian skor masing-masing dijumlahkan.

Penilaian perilaku diukur dengan menggunakan skala Likert, diukur dengan memberikan 10 pernyataan, kemudian skor masing-masing dijumlahkan. Untuk menilai status karies gigi digunakan nilai DMF-T (Decay Missing Filling Teeth). Nilai DMF-T adalah angka yang menunjukkan jumlah gigi dengan karies pada seseorang atau sekelompok orang. Untuk gigi sulung digunakan digunakan indeks def-t.

\section{HASIL PENELITIAN}

Tabel 1 Distribusi Responden Berdasarkan Jenis Kelamin Pada Siswa SD Inpres Pattiro Kec. Manuju Kab. Gowa

\begin{tabular}{|l|c|c|}
\hline \multicolumn{1}{|c|}{ Jenis Kelamin } & Jumlah (n) & Persentasi (\%) \\
\hline Laki-laki & 20 & 58,8 \\
\hline Perempuan & 14 & 41,2 \\
\hline \multicolumn{1}{|c|}{ Total } & 34 & 100 \\
\hline
\end{tabular}


Berdasarkan tabel di atas diketahui 20 orang $(58,8 \%)$, dan perempuan sebanyak 14 bahwa dari 34 responden, didapatkan orang $(41,2 \%)$.

responden berjenis kelamin laki-laki sebanyak

Tabel 2 Distribusi Responden Berdasarkan Sikap Terhadap Karies Gigi Pada Siswa SD Inpres Pattiro Kec. Manuju Kab. Gowa.

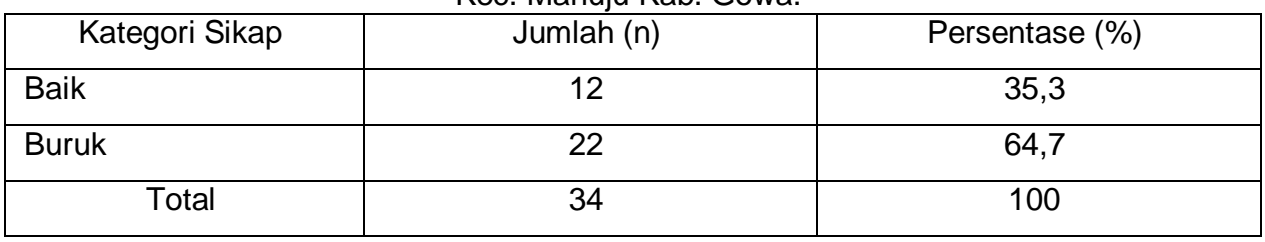

Berdasarkan tabel di atas dengan kategori buruk, dan 12 responden menunjukkan bahwa dari 34 responden (35,3\%) yang memiliki sikap dengan kategori didapatkan sebanyak 22 responden $(64,7 \%) \quad$ baik.

Tabel 3 Distribusi Responden Berdasarkan Perilaku Terhadap Karies Gigi Pada Siswa SD Inpres Pattiro Kec. Manuju Kab. Gowa

\begin{tabular}{|c|c|c|}
\hline Kategori Perilaku & Jumlah (n) & Persentase (\%) \\
\hline Baik & 11 & 32,4 \\
\hline Buruk & 23 & 67,6 \\
\hline Total & 34 & 100 \\
\hline
\end{tabular}

Berdasarkan tabel di atas menunjukkan bahwa dari 34 responden didapatkan sebanyak 23 responden $(67,6 \%)$ dengan kategori buruk, dan 11 responden (32,4\%) yang memiliki perilaku dengan kategori baik.

Tabel 4 Distribusi Berdasarlan Indeks Karies Gigi Siswa SD Inpres Pattiro Kec. Manuju Kab. Gowa

\begin{tabular}{|l|c|c|c|}
\hline \multicolumn{1}{|c|}{ Indeks Karies } & Jumlah $(\mathrm{n})$ & Rerata & Kategori \\
\hline DMF-T & 28 & 1,03 & Sangat Rendah \\
\hline def-t & 257 & 7,56 & Sangat Tinggi \\
\hline
\end{tabular}

Berdasarkan tabel di atas termasuk dalam kategori sangat rendah, menunjukkan bahwa nilai DMF-T rata-rata pada sedangkan nilai def-t rata-rata yaitu 7,56 siswa SD Inpres Pattiro yaitu 1,03 dimana dimana termasuk dalam kategori sangat tinggl.

Tabel 5 Distribusi Sikap dan Perilaku Terhadap Indeks Karies Gigi Siswa SD Inpres Pattiro Kec. Manuju

\begin{tabular}{|c|c|c|c|c|c|}
\hline & Kategori & DMF-T & Rerata & def-t & Rerata \\
\hline \multirow{3}{*}{ Sikap } & Baik & 8 & $\begin{array}{c}0,8 \text { (sangat } \\
\text { rendah }\end{array}$ & 71 & 5,91 (tinggi) \\
\cline { 2 - 6 } & Buruk & 20 & $\begin{array}{c}1,17 \text { (sagat } \\
\text { rendah) }\end{array}$ & 186 & $\begin{array}{c}8,17 \text { (sangat } \\
\text { tinggi) }\end{array}$ \\
\hline Perilaku & Baik & 6 & $\begin{array}{c}0,85 \text { (sangat } \\
\text { rendah) }\end{array}$ & 64 & 8,2 (sangat tinggi) \\
\cline { 2 - 6 } & Buruk & 22 & $\begin{array}{c}1,05(\text { sangat } \\
\text { rendah) }\end{array}$ & 193 & $\begin{array}{c}8,39 \text { (sangat } \\
\text { tinggi) }\end{array}$ \\
\hline
\end{tabular}




\begin{abstract}
Berdasarkan tabel di atas menunjukkan bahwa kategori sikap buruk memiliki nilai rerata DMF-T dan def-t yang paling tinggi dengan nilai rerata DMF-T 1,17 tergolong sangat rendah dan rerata def-t dengan nilai 8,17 yang tergolong sangat tinggi. Sedangkan kategori perilaku buruk memiliki nilai rerata DMF-T dan def-t yang paling tinggi dengan nilai rerata DMF-T 1,05 tergolong sangat rendah dan rerata def-t dengan nilai 8,39 yang tergolong sangat tinggi.
\end{abstract}

\section{PEMBAHASAN}

Hasil penelitian, diperoleh gambaran sikap dan perilaku terhadap karies yang diperoleh dari data kuesioner yang diberikan kepada siswa SD Inpres Pattiro. Untuk sikap terhadap karies diperoleh hasil dengan kategori baik sebanyak 12 siswa (35,3\%), dan 22 siswa $(64,7 \%)$ yang memiliki kategori buruk. Hal ini disebabkan karena pengetahuan siswa yang masih rendah. Ada tiga komponen pokok yang membentuk sikap seperti yang dikemukakan oleh Allport (1954) yaitu, kepercayaan (keyakinan), kehidupan emosional, dan kecendrungan untuk beritindak. Ketiga hal inilah yang bersama-sama membentuk sikap yang utuh. Dalam penentuan sikap yang utuh ini, pengetahuan, pikiran, keyakinan dan emosi memegang peranan penting.

Sedangkan pada hasil perilaku terhadap karies diperoleh sebanyak 11 siswa $(32,4 \%)$ dengan kategori baik, dan 23 siswa $(67,6 \%)$ yang memiliki kategori buruk. Hal ini disebabkan karena siswa menganggap menjaga kebersihan mulut tidaklah begitu penting. Ada beberapa faktor yang mempengaruhi pembentukan perilaku seseorang diantaranya pengetahuan, sikap, motivasi, emosi, serta lingkungan sekitar.
Hasil penelitian ini menunjukkan bahwa nilai DMF-T pada siswa SD Inpres Pattiro Kec. Manuju Kab. Gowa sebanyak 28 dengan nilai rerata 1,03 yang berdasarkan kriteria WHO tergolong sangat rendah. Hal ini disebabkan usia responden 6-10 tahun sehingga jumlah gigi permanen yang tumbuh masih sedikit.

Sedangkan nilai def-t sebanyak 257 dengan nilai rerata 7,57 yang berdasarkan kriteria WHO tergolong sangat tinggi. Hal ini dikarenakan usia yang paling rentan untuk terjadinya karies gigi adalah usia 4-8 tahun, karena pada saat gigi susu (primer) akan bertahan sampai umur 6 tahun. Perlu diketahui bahwa pada usia 6-12 tahun adalah masa peralihan antara gigi susu dengan gigi tetap. Maka antara usia tersebut disebut pula masa gigi bercampur atau gigi peralihan. Gigi yang paling akhir erupsi lebih rentan terhadap karies gigi (Ircham Mahfeods, 1994).

Hasil penelitian ini menunjukkan bahwa sikap dan perilaku berbanding lurus dengan indeks karies responden. Semakin baik sikap dan perilaku responden maka indeks karies semakin rendah. Hal ini menunjukkan bahwa salah satu faktor yang mempengaruhi tingginya indeks karies gigi responden adalah sikap dan perilakunya. Menurut Natoadmojo yang dikutip Samuel dkk (2014), pengetahuan seseorang akan menentukan perilakunya dalam hal kesehatan. Seseorang yang mempunyai pengetahuan yang baik, maka akan tahu tindakan yang tepat apabila terserang suatu penyakit.

Hasil penelitian ini didukung oleh penelitian Ainun Nur Afiah (2016) pada pelajar SMP Pondok Pesantren Ummul Mukminin yang memperoleh hasil adanya hubungan yang bermakna antara pengetahuan, sikap, dan tindakan pemeliharaan kesehatan gigi dan 
mulut terhadap status kesehatan gigi, dimana semaki tinggi nilai pengetahuan, sikap, dan tindakan maka semakin redah nilai DMF-T. Hal ini juga sejalan dengan penelitian E.R Widi (2003) yang mengemukakan bahwa salah satu faktor yang mempengaruhi status kesehatan gigi dan mulut adalah perilaku.

\section{KESIMPULAN}

1. Sikap terhadap karies gigi pada siswa SD Inpres Pattiro Kec.Manuju Kab. Gowa mayoritas berada pada kategori buruk $(64,7 \%)$

2. Perilaku terhadap karies gigi pada siswa SD Inpres Pattiro Kec.Manuju Kab. Gowa mayoritas berada pada kategori buruk $(67,6 \%)$

3. Indeks karies gigi pada siswa SD Inpres Pattiro Kec.Manuju Kab. Gowa tergolong sangat tinggi ditunjukkan degan nilai rerata def-t 7,56.

4. Semakin buruk sikap dan perilaku siswa maka semakin tinggi pula tingkat keparahan kariesnya.

\section{SARAN}

1. Bagi institusi sekolah dasar, perlu meningkatkan program pendidikan kesehatan gigi yang lebih baik.

2. Bagi dinas kesehatan dapat memaksimalkan fungsi Usaha Kesehatan Gigi Sekolah (UKGS) di seluruh sekolah dan membuat program penyuluhan kesehatan gigi bagi masyarakat yang ada di sekolah secara berkala.

3. Bagi orang tua diharapkan dapat memberi motivasi, pendidikan, dan perilaku pemeliharaan kesehatan gigi yang benar terhadap anak sehingga nantinya anak tersebut dapat memelihara kesehatan giginya secara mandiri.

4. Bagi peneliti selanjutnya diharapkan dari hasil penelitian ini dapat memberikan manfaat dan sebagai bahan masukan mengenai sikap dan perilaku terhadap karies gigi.

\section{DAFTAR PUSTAKA}

Agusta Maria V, Ismail Ade \& Firdausy Muhammad D, 2015, 'Hubungan pengetahuan kesehatan gigi dengan kondisi oral hygiene anak tunarungu usia sekolah', Medali Jurnal.

Budiharto, 2013, 'Pengantar ilmu perilaku kesehatan dan pendidikan kesehatan gigi'. Jakarta: EGC, Hal. 17-24.

Dorland WM, 2010, Kamus Kedokteran Dorland (Terjemahan), Edisi 31, Jakarta: EGC

Fajerskov O, Edwina Kid, 2008, Dental caries the diases and its clinical management. 2nd ed. United Kingdom: Munksgaard Blackwell.

Kementrian Kesehatan RI, 2013, Riset kesehatan dasar RISKESDAS 2013. Indonesia: Kementrian Kesehatan RI.

Kidd Edwina, Joyston \& Bachal Sally, 2012, Dasar-dasar karies: penyakit dan penannggulangannya. Jakarta: Buku Kedokteran EGC: Hal. 14-16.

Notoadmodjo S, 2007, Promosi Kesehatan dan ilmu perilaku. Jakarta: Rinneka Cipta; Hal. 133-148.

Ozdemir Dogan, November 2014, Dental caries and preventive strategis. Journal of educational and instructional studies in the world; 4(4): 20-24.

Putri Megananda $\mathrm{H}$, Herijulianti Eliza, Nurjannah Neneng. IImu pencegahan penyakit jaringan keras dan jaringan pendukung gigi. Jakarta: Buku kedokteran EGC; 2009: 154-156

Prasetya Tri I, 2012, Meningkatkan keterampilan menyusun instrument hasil belajar berbasis modul interaktif bagi guru-guru IPA SMPN kota Magelang. Journal of Educational Research and Evaluation; 1(2): 106112.

Sariningsih, Endang. 2012. Merawat Gigi Anak Sejak Usia Dini. Jakarta: Gramedia Jurnal of Public Health Researh and Development 1 (1) 2017.

Suciari, Ana, Arief, Yuni Sufyanti, Rachmawati \& Praba Diyan, 2015, Peran Orang Tua dalam Membimbing Menyikat Gigi dengan Kejadian Karies Gigi Anak Prasekolah. Program Studi Pendidikan, Fakultas Keperawatan Universitas Airlangga, Journal of Dinamika Kesehatan, Vol. 8 No. 1. 